\title{
Peran Vasodilator pada Gagal Jantung Anak
}

\author{
Sri Sofyani
}

\begin{abstract}
Vasodilator dapat menurunkan tahanan vaskular sistemik dengan memperlebar pembuluh darah arteriol (mengurangi afterload) dan/atau menurunkan preload (tekanan pengisian ventrikel kiri dengan venodilatasi) terbukti berperan dalam penanganan gagal jantung kongestif. Pada pasien gagal jantung berat, jika pengobatan konvensional tidak adekuat maka penggunaan vasodilator sangat bermanfaat. Pada anak, pemberian vasodilator diindikasikan pada keadaan tidak responsif terhadap pengobatan konvensional, pada persiapan operasi, keadaan menunggu saat operasi jantung, pasca operasi jantung dan jika diperlukan penurunan preload dan/atau after load. Pada makalah ini dibahas beberapa jenis vasodilator yang sering dipakai pada gagal jantung anak.
\end{abstract}

Kata kunci: vasodilator - gagal jantung.

p

emakaian vasodilator untuk bayi dan anak yang mengalami gagal jantung merupakan konsep yang relatif baru. ${ }^{1}$ Makalah yang membahas mengenai pemakaian berbagai jenis vasodilator, dan dampak hemodinamiknya dalam pemakaian jangka pendek maupun jangka panjang terutama berdasarkan penelitian pada orang dewasa. Sangat sedikit penelitian eksperimental yang dipublikasikan mengenai dampak vasodilator pada bayi dan anak. ${ }^{1,2}$

Cohn dan Franciosa pada tahun 1977 adalah orang pertama yang mengemukakan peran vasodilator pada gagal jantung. ${ }^{3}$ Pada pasien gagal jantung berat, forward failure lebih dominan maka pengobatan konvensional yang meliputi pemberian obat inotropik untuk memperbaiki kontraktilitas otot jantung dan diuretik untuk meningkatkan ekskresi natrium melalui ginjal, seringkali tidak adekuat. Guna mengurangi gejala kongestif dan memperbaiki curah jantung, penggunaan vasodilator sangat bermanfaat. ${ }^{3}$ Tujuan tulisan ini adalah untuk mengemukakan peranan vasodilator pada gagal jantung anak.

\footnotetext{
Alamat korespondensi:

Dr. Sri Sofyani, Sp.A.

Bagian Ilmu Kesehatan Anak, Fakultas Kedokteran Universitas Sumatera

Utara/RS H Adam Malik. Jl. Bunga Lau No. 17 Medan.

Telepon 836 0405, 836 0143, 836 034. Fax. 8361721.
}

\section{Patofisiologi Gagal Jantung}

Gagal jantung merupakan suatu sindrom klinis yang disebabkan oleh gagalnya mekanisme kompensasi otot jantung dalam mengantisipasi peningkatan beban volume ataupun beban tekanan yang berlebih yang sedang dihadapinya, sehingga tidak mampu memompakan darah untuk memenuhi kebutuhan metabolisme jaringan tubuh. ${ }^{4-13}$ Kemampuan jantung untuk memompa darah guna memenuhi kebutuhan tubuh ditentukan oleh curah jantung yang dipengaruhi oleh empat faktor yaitu ${ }^{4-6,12,14-15}$

(1) preload (volume work) yang setara dengan isi diastolik akhir.

(2) after load, (pressure work) yaitu jumlah resistensi total, yang harus dilawan saat ventrikel berkontraksi,

(3) kontraktilitas miokardium, yaitu kemampuan intrinsik otot jantung untuk menghasilkan tenaga dan berkontraksi tanpa tergantung kepada preload maupun after load serta,

(4) frekuensi denyut jantung.

\section{Preload}

Preload atau beban diastolik adalah fungsi dari alir balik dan kelenturan ventrikel, yang menentukan isi dan tekanan atrium kanan dan kiri. Dalam prakteknya, preload diperkirakan dengan pengukuran tekanan vena sentral sebagai pengganti tekanan atrium kanan, dan tekanan baji paru (pulmonary wedge pressure) sebagai 
pengganti tekanan atrium kiri. Sesuai dengan hukum Starling, bertambahnya volume diastolik akhir sampai titik optimal akan meningkatkan curah jantung. ${ }^{4-6,12,14-}$ 18

\section{Afterload}

Afterload merupakan tahanan yang harus dilawan jantung pada saat memompa darah. ${ }^{15}$ Resistensi vaskular sistemik sering meningkat pada pasien gagal jantung kongestif. Apabila afterload meningkat maka isi sekuncup dan curah jantung menurun, akibatnya terjadi refleks peningkatan resistensi vaskular sistemik antara lain dengan peningkatan simpatis dan katekolamin yang bersirkulasi. ${ }^{15} \mathrm{Hal}$ ini kemudian akan memperkecil curah jantung; sebaliknya, berkurangnya afterload akan meningkatkan curah jantung.

Tekanan aorta sering dipakai untuk memperkirakan afterload. ${ }^{6}$ Di dalam klinik penilaian efektifitas suatu obat untuk menurunkan afterload dilakukan dengan cara mengukur tekanan darah dan frekuensi jantung serta menilai perfusi perifer. Apabila perfusi perifer membaik dan tekanan darah aorta relatif konstan, dan tidak terdapat peningkatan frekuensi jantung yang bermakna, maka dapat diperkirakan terdapat peningkatan isi sekuncup dan curah jantung. Sebaliknya, walaupun perfusi perifer kelihatan membaik, apabila terdapat hipotensi disertai takikardia, menunjukkan terdapatnya curah jantung yang rendah yang potensial membahayakan jiwa. ${ }^{6}$

\section{Kontraktilitas}

Kontraktilitas merupakan kekuatan kontraksi otot jantung. Derajat aktivitas serabut jantung ditentukan oleh kuantitas penyediaan ion $\mathrm{Ca}++$ untuk protein kontraktil. Derajat maupun intensitas aktivitas miokardium sangat menentukan keadaan inotropik atau kontraktilitas otot jantung. Perubahan kontraktilitas adalah perubahan fungsi jantung yang tidak tergantung kepada variabilitas preload maupun afterload. Pada setiap tingkat preload atau afterload, stimulasi inotropik berpengaruh terhadap penampilan jantung. ${ }^{4,6,7,12,14-18}$

\section{Frekuensi Denyut Jantung}

Sesuai dengan rumus bahwa curah jantung sama dengan isi sekuncup dikalikan dengan frekuensi jantung, maka peningkatan frekuensi jantung memperbesar curah jantung. Tetapi frekuensi denyut jantung yang terlalu tinggi dapat berakibat turunnya curah jantung oleh karena (1) berkurangnya isi diastolik akhir, (2) peningkatan konsumsi oksigen yang mengakibatkan dampak inotropik negatif, dan (3) kurangnya perfusi koroner.

Beban jantung yang berlebihan pada preload terjadi pada defek pirau kiri ke kanan, regurgitasi katup atau fistula arteriovena. ${ }^{6}$ Sedangkan beban yang berlebihan pada afterload terjadi pada obstruksi jalan keluar jantung, misalnya stenosis aorta, stenosis pulmonal, dan koarktasio aorta. ${ }^{6,12}$

Mekanisme kompensasi pada gagal jantung bertujuan mempertahankan fungsi miokard antara lain dengan aktivasi sistem renin angiotensin-aldosteron (RAA) dan sistem saraf simpatis untuk mempertahankan pengisian jantung. ${ }^{6,9,14-16}$ Mekanisme ini pada mulanya diimbangi dengan dilepasnya zat pengatur endogen untuk memacu natriuresis dan vasodilatasi sehingga tercapai kembali keseimbangan homeostasis. Namun pada gagal jantung yang berlanjut keseimbangan ini akan bergeser sehingga vasokonstriksi dan retensi cairan yang mencolok. Lama kelamaan beban jantung semakin berat karena resistensi perifer yang meningkat, maka vasodilator berperan mengurangi vasokonstriksi yang berlebihan ini. ${ }^{6,15,16}$

Gagal jantung kongestif pada anak dapat diakibatkan karena kelainan kongenital maupun kelainan yang didapat, tetapi sebagian besar diakibatkan oleh kelainan jantung kongenital yang mengalami pemburukkan karena adanya peningkatan beban volume dan atau peningkatan tekanan. ${ }^{19,20}$ Penyakit jantung didapat yang dapat menyebabkan gagal jantung pada anak adalah kardiomiopati kongestif atau sebagai sekuele demam rematik. ${ }^{19}$

Mengingat penyebab tersering gagal jantung pada anak adalah kelainan kongenital, maka terapi utama adalah operasi. ${ }^{19}$ Terapi dengan obat-obatan bertujuan untuk mempersiapkan anak menjalani operasi, mempertahankan fungsi jantung dan mencegah penyakit menjadi progresif. ${ }^{19,20}$ Jika operasi tidak dapat dilakukan maka terapi medikamentosa menjadi terapi pilihan utama. ${ }^{20}$

Obat vasodilator dapat menurunkan tahanan vaskular sistemik dengan mengurangi afterload dan/ atau menurunkan preload, terbukti berperan dalam penanganan gagal jantung kongestif., ${ }^{6,1420}$ (Tabel 1)

Sistem vena berisi $70-75 \%$ volume darah, sehingga 
Tabel 1. Indikasi pemberian obat vasodilator pada gagal jantung bayi dan anak

- Tidak responsif terhadap pengobatan konvensional

- Jika diperlukan penurunan preload dan/atau afterload

- $\quad$ Persiapan operasi atau keadaan menunggu saat operasi jantung

- $\quad$ Pasca operasi jantung

berperan sebagai sistem penampungan atau penyimpanan utama bagi sistem vaskular perifer. ${ }^{15}$ Pada gagal jantung kongestif terdapat peningkatan tonus simpatis dan katekolamin yang bersirkulasi. ${ }^{15,21}$ Mekanisme kompensasi ini mempertahankan aliran balik vena ke jantung, tetapi kemudian akan menambah kelebihan beban ventrikel kanan dan sirkulasi paru. Karena itu vasodilator yang secara selektif memperlebar vena misalnya nitrogliserin, dapat bermanfaat untuk mengalirkan kembali darah ke dalam vaskular serta menurunkan tekanan atrium kanan dan kiri. ${ }^{15}$

Respons terhadap vasodilator tampak lebih baik pada pasien gagal jantung kongestif akut daripada kongestif kronik. ${ }^{20}$ Untuk gagal jantung kronik vasodilator diberikan pada regurgitasi valvular dan berbagai tipe kardiomiopati dilatasi. ${ }^{20}$ (Tabel 2)

\section{Klasifikasi Vasodilator}

Menurut tempat kerjanya vasodilator dikelompokkan sebagai vasodilator arteri misalnya hidralazin, vasodilator vena misalnya nitrat atau kombinasi vasodilator arteri dan vena misalnya nitroprusid, prazosin dan kaptopril. $6,15,20$

Klasifikasi yang lain berdasarkan cara kerjanya. ${ }^{18,22}$ Vasodilator yang bekerja langsung pada pembuluh darah dan tidak langsung yaitu melalui mekanisme neurohumoral atau reseptor tertentu. ${ }^{20}$ Vasodilator yang bekerja langsung contohnya sodium nitroprusid, nitrat, minoksidil dan hidralazin. Sedangkan contoh vasodilator tidak langsung adalah penyekat alfaadrenergik (prazosin), antagonis kalsium (nifedifin) dan inhibitor ACE misalnya kaptopril (Tabel 3). ${ }^{20,22}$ Secara praktis, vasodilator dibedakan juga menurut jangka waktu penggunaannya. ${ }^{18}$ Vasodilator parenteral, misalnya $\mathrm{Na}$-nitroprusid atau nitrogliserin digunakan dalam jangka pendek untuk gagal jantung kronik yang
Tabel 2. Indikasi keadaan klinis pemberian obat vasodilator

- Miokarditis dengan gagal jantung akut ataupun kronik

- Kardiomiopati kongestif

- Regurgitasi katup atrioventrikular sistemik yang berat. - regurgitasi mitral

- L-transposition dengan regurgitasi trikuspidal

- D-transposition dengan regurgitasi trikuspidal

- Regurgitasi aorta

- Pirau dari kiri ke kanan intrakardiak yang besar

- Pasca koreksi kelainan jantung kongenital dengan disfungsi ventrikel kiri misalnya Tetralogi Fallot, anomali arteri koronaria kiri, koarktasio kompleks, dan defek septum atrioventrikular.

- Hipertensi renovaskular

Tabel 3. Vasodilator oral pada gagal jantung

\begin{tabular}{ll}
\hline Golongan vasodilator & Preparat obat \\
Penyekat alfa adrenergik & Prazosin \\
Inhibitor ACE & Kaptoril \\
& Enalapril \\
Antagonis kalsium & Nifedipin \\
Relaksan otot polos & Hidralazin \\
& Minoksidil
\end{tabular}

mengalami eksaserbasi akut berat yang tak teratasi oleh digitalis dan diuretik, juga untuk gagal jantung kiri akut yang disertai edem paru. ${ }^{18}$ Pemberian vasodilator oral jangka pendek ditujukan untuk gagal jantung kronik. Dalam kelompok ini termasuk inhibitor ACE dan vasodilator oral lainnya. ${ }^{18}$

Pemilihan vasodilator disesuaikan dengan keadaan hemodinamik pasien gagal jantung dan tujuan utama pengobatan, apakah untuk menurunkan beban awal (preload) ataupun beban akhir (afterload). 14,15,20,23 Jika gejala kongesti yang mencolok dengan tekanan pengisian yang tinggi dan gejala utama dispne maka dipilih venodilator; ${ }^{12,15,21,23}$ sedangkan pada keadaan curah jantung rendah yang lebih dominan dan manifestasi klinik yang mencolok adalah fatigue maka dipilih arteriodilator. ${ }^{12,15,20}$ Dalam praktek, seringkali digunakan obat kombinasi arterio dan venodilator untuk mengurangi baik preload maupun afterload. ${ }^{15,20}$

Dampak vasodilatasi yang terjadi berhubungan dengan dosis. ${ }^{20}$ Artinya jika dosis yang diberikan lebih tinggi, maka efek vasodilatasi akan lebih besar. ${ }^{24}$ Evaluasi klinik yang cermat dan menyeluruh sangat diperlukan 
dan merupakan metode yang praktis dalam memantau efikasi vasodilator pada gagal jantung kongestif., ${ }^{6,20,23}$ Kontraindikasi vasodilator adalah gagal jantung dengan kardiomiopati restriktif dan hipertropik. ${ }^{10}$

Sampai saat ini umumnya vasodilator diberikan sebagai tambahan terhadap terapi standar. ${ }^{1,15,25}$ Diperlukan penyelidikan yang lebih lanjut untuk menentukan apakah terapi vasodilatasi bisa dianggap sebagai terapi primer atau tidak sebelum pemberian digitalis atau diuretik. ${ }^{1,15,26}$ Beberapa vasodilator yang sering dipakai untuk pengobatan gagal jantung tertera pada Tabel 4 dan dasar pemberian vasodilator dapat dilihat pada Tabel 5

Beberapa jenis vasodilator yang sering dipakai pada gagal jantung anak

Nitrogliserin adalah vasodilator yang paling tua dan telah digunakan secara luas pada pasien dewasa. ${ }^{16}$ Obat ini mempunyai dampak vasodilator langsung pada otot polos pembuluh darah, terutama pada vena besar. ${ }^{20}$ Kerjanya melalui pelepasan oksida nitrit, diduga merupakan endothelial-derived relaxing factor, yang menyebabkan terjadinya relaksasi capitance vessels (venodilatasi). ${ }^{24}$ Berakibat kapasitas vena meningkat sehingga terjadi penurunan tekanan pengisian ventrikel (ventricular filling pressures). ${ }^{23}$ Berdasarkan hal tersebut, indikasi pemberian obat ini adalah pada gagal jantung yang mengalami kenaikan preload dan terdapat tanda kongesti pulmonal dan vena sistemik. ${ }^{6,23}$ Pengalaman pemakaian obat ini pada bayi dan anak tidak banyak. Benson dan kawan-kawan ${ }^{27}$ melaporkan pemakaian infus nitrogliserin selama masa awal pasca operasi jantung, menunjukkan adanya perbaikan klinis yang nyata. Dosis 0,4-60 ug $/ \mathrm{kg} / \mathrm{menit}$ dengan kecepatan pemberian rata-rata $20 \mathrm{ug} / \mathrm{kg} /$ menit didapatkan peningkatan cardiac index yang secara statistik sangat bermakna. $^{27}$

Tabel 4. Rekomendasi pemakaian vasodilator pada bayi dan anak

\begin{tabular}{|c|c|c|}
\hline Obat & Dosis dan cara pemberian & Indikasi klinis secara umum \\
\hline Nitrogliserin & $\begin{array}{l}1-5 \mathrm{ug} / \mathrm{kg} / \mathrm{menit} \mathrm{IV} ; \text { maksimum } 10 \\
\mathrm{ug} / \mathrm{kg} / \mathrm{menit}\end{array}$ & $\begin{array}{l}\text { Pasca operasi low cardiac outputsyndrome, } \\
\text { hipertensi pulmonal, dan } \\
\text { /atau kongesti vena }\end{array}$ \\
\hline Hidralazin & $\begin{array}{l}0,1-0,5 \mathrm{mg} / \mathrm{kg} / \mathrm{dosis} \text { IV; tiap 6-8 jam } \\
0,25-1,0 \mathrm{mg} / \mathrm{kg} / \text { dosis oral tiap 6-8 jam. } \\
\text { Maksimum } 7 \mathrm{mg} / \mathrm{kg} / \text { hari }\end{array}$ & $\begin{array}{l}\text { Disfungsi ventrikel kronik, regurgitasi } \\
\text { aorta dan/atau regurgitasi mitral } \\
\text { Pirau dari sistemik ke pulmonal }\end{array}$ \\
\hline Nifedipin & $\begin{array}{l}\text { Bayi: } 0,1-0,3 \mathrm{mg} / \mathrm{kg} / \mathrm{dosis} \\
\text { Anak: } 0,2-0,5 \mathrm{mg} / \mathrm{kg} / \mathrm{dosis} \text { sublingual } \\
\text { tiap } 6 \text { jam atau oral tiap } 8 \text { jam }\end{array}$ & $\begin{array}{l}\text { Regurgitasi aorta dan/atau regurgitasi } \\
\text { mitral } \\
\text { Pirau dari sistemik ke pulmonal }\end{array}$ \\
\hline Nitroprusid & $\begin{array}{l}0,5-3,0 \mathrm{ug} / \mathrm{kg} / \mathrm{menit} \text { IV } \\
\text { Maksimum } 10 \mathrm{ug} / \mathrm{kg} / \text { menit }\end{array}$ & $\begin{array}{l}\text { Pasca operasi low cardiac output sydrome, } \\
\text { hipertensi pulmonal, dan } \\
\text { /atau kongesti vena sistematik }\end{array}$ \\
\hline entolamin & $2,5-15 \mathrm{ug} / \mathrm{kg} / \mathrm{menit}$ IV & Pasca operasi low cardiac output sydrome \\
\hline Kapto & $\begin{array}{l}\text { Neonatus: } 0,1-1,5 \mathrm{mg} / \mathrm{kg} / \mathrm{dosis} \text { oral } \\
\text { tiap 8-12 jam.Maksimum } 4 \mathrm{mg} / \mathrm{kg} / \text { hari } \\
\text { Bayi dan anak: } 0,1-2,0 \mathrm{mg} / \mathrm{kg} / \mathrm{dosis} \text { oral } \\
\text { tiap 6- } 12 \text { jam.Maksimum } 6 \mathrm{mg} / \mathrm{kg} / \text { hari } \\
\text { Remaja6,25-12,5 mg } / \mathrm{kg} / \mathrm{dosis} \text { oral } \\
\text { tiap 8-12 jam untuk Maksimum } 50-75 \\
\text { mg/dosis }\end{array}$ & $\begin{array}{l}\text { Disfungsiventrikel kronik.Regurgitasi } \\
\text { aorta dan/atau regurgitasi mitral. } \\
\text { Pirau dari sistemik ke pulmonal }\end{array}$ \\
\hline Enalapril & $\begin{array}{l}\text { Anak dan remaja: 0,08 0,1-1,5 mg/kg/ } \\
\text { dosis oralsetiap 12-24 jam }\end{array}$ & $\begin{array}{l}\text { Disfungsiventrikel kronik.Regurgitasi } \\
\text { aorta dan/atau regurgitasi mitral. } \\
\text { Pirau dari sistemik ke pulmonal }\end{array}$ \\
\hline Prazosin & $\begin{array}{l}\text { 0,01-0,05 mg/kg/dosis oralsetiap } \\
6-8 \text { jam.Maksimum } 0,10 \mathrm{mg} / \mathrm{kg} / \text { dosis }\end{array}$ & $\begin{array}{l}\text { Disfungsi ventrikel kronik.Regurgitasi } \\
\text { aorta dan/atau regurgitasi mitral. }\end{array}$ \\
\hline
\end{tabular}


Tabel 5. Dasar pemberian vasodilator pada gagal jantung

- Gagal jantung yang signifikan akibat disfungsi ventrikel kiri apapun penyebabnya yang tidak responsif terhadap terapi konvensional (digoksin dan diuretik).

- Pada beberapa pasien vasodilator perlu dipertimbangkan sebelum pengobatan obat inotropik.

- Pengawasan harus dilakukan jika dijumpai hipotensi dan penurunan tekanan darah yang berarti.

- Pemilihan jenis vasodilator yang dipakai tergantung keadaan hemodinamik pasien

- Late tolerance terhadap efek vasodilator mungkin disebabkan karena retensi cairan dan peningkatan berat badan. Peningkatan dosis diuretik mungkin bermanfaat. Peningkatan

dosis vasodilator atau mengganti jenis vasodilator yang dipakai perlu dipertimbangkan.

Efek samping nitrogliserin adalah hipotensi, takikardi, hipoksemia, mual, muntah dan sakit kepala. ${ }^{4,23}$ Obat ini dapat diberikan melalui intra vena, sublingual dan trasdermal. ${ }^{4,23}$

Nitroprusid adalah vasodilator yang bekerja langsung pada otot polos arteri dan vena. ${ }^{1,4,12}$ Dampak timbul dalam beberapa menit setelah infus nitroprusid diberikan dan dampak hilang dengan cepat., ${ }^{1,22} \mathrm{Di}$ dalam sel darah merah nitroprusid dipecah menjadi cyan methemoglobin dan sianida bebas, kemudian sianida bersama tiosulfat diubah menjadi tiosianat oleh sel hati ${ }^{12,24}$ dan dikeluarkan melalui ginjal. ${ }^{1,723}$ Bila ginjal terganggu, penggunaan nitroprusid dapat menimbulkan hipotiroid akibat keracunan tiosianat ${ }^{12,22}$ oleh karena itu pada pasien ini harus dikurangi sedikit demi sedikit atau dihentikan pada kadar serum lebih tinggi dari pada $6 \mathrm{mg} / \mathrm{dl} .^{1,12,23}$

Manfaat hemodinamik yang terjadi adalah penurunan tekanan arteri sistemik dan paru, penurunan tekanan kapiler paru, serta peningkatan cardiac index. ${ }^{16} \mathrm{Di}$ samping itu didapatkan pula penurunan volume akhir diastolik dan akhir sistolik ventrikel kiri. Diberikan dengan dosis yang rendah pada awal pemberian kemudian dinaikkan perlahan untuk mendapatkan dampak yang optimal, oleh karena itu obat ini sering digunakan di ruangan perawatan intensif dengan pengawasan yang ketat pada pasien gagal jantung akut dengan tekanan darah adekuat untuk mempertahankan perfusi serebral dan renal. ${ }^{16}$ Penurunan dosis juga harus perlahan-lahan, hal lain yang perlu diperhatikan adalah menghindari ekstravasasi dan sinar. ${ }^{16}$ Larutan obat ini disiapkan segera sebelum dipakai, tidak boleh dipakai lagi setelah 4 jam, dan tidak boleh dicampur dengan obat lain. ${ }^{1}$

Nitroprusid bersifat toksis pada dosis yang tinggi dan bila diberikan dalam waktu lama. Pada pemakaian nitroprusid dengan dosis berlebihan dapat menyebabkan penurunan tekanan diastolik akhir ventrikel kiri dan hipotensi yang hebat, yang dapat hilang dengan menghentikan obat selama $10-15$ menit. ${ }^{12}$ Jika hipotensi berat terjadi pemberian cairan dan/atau vasokonstriktor pada waktu yang bersamaan seperti fenilefrin atau epinefrin mungkin diperlukan. ${ }^{12,22}$ Iskemia miokard, lelah, mual, muntah, metabolik asidosis, dypsne, sakit kepala, ataksia serta disorientasi dapat pula terjadi akibat pemakaian nitroprusid terutama bila dipakai terus menerus lebih dari 48 jam. ${ }^{7}$ Jika dipakai dalam waktu lama kadar tiosianat darah harus dimonitor dan tidak lebih dari $12 \mathrm{mg} / \mathrm{dl}^{11}$, walaupun ada yang mengatakan tidak boleh lebih dari $10 \mathrm{mg} / \mathrm{dl} .^{7}$

Keracunan sianida dapat menimbulkan koma, hilangnya refleks pupil, kulit merah jambu, hipotensi dan asidosis laktat. ${ }^{20}$

Hidralazin dapat diberikan secara parenteral atau oral, bekerja langsung menyebabkan relaksasi otot polos, terutama pembuluh darah arteriol prekapiler. Vasodilatasi yang timbul relatif selektif, aliran darah ke ginjal dan ekstremitas meningkat sedangkan aliran darah ke hati tidak banyak berubah. Selain itu hidralazin juga mempunyai efek venodilator ringan. ${ }^{28}$

Pada gagal jantung, hidralazin mengurangi afterload ventrikel kanan dan kiri dengan mengurangi resistensi vaskular sistemik termasuk resistensi vaskuler paru tanpa diikuti oleh perubahan aktifitas refleks susunan saraf pusat kecuali terjadinya hipotensi. ${ }^{16} \mathrm{Hal}$ ini menyebabkan peningkatan isi sekuncup dan penurunan fraksi regurgitasi pada insufisiensi mitral. Hidralazin juga mempunyai aktifitas inotropik positif pada otot jantung yang tidak berhubungan dengan pengurangan afterload. ${ }^{16}$

Michael Artman dan kawan-kawan ${ }^{13,19}$ mendapatkan adanya respons yang segera pada pemakaian hidralazin saat dilakukan kateterisasi. Mereka mengukur tekanan darah sistemik, cardiac output dan tekanan pengisisian vertikel kiri sebelum dan sesudah pemberian hidralazin intravena, dengan dosis $0,5 \mathrm{mg} / \mathrm{kg}$ IV. Pengukuran hemodinamik dilakukan tiap 20 menit, jika efek masih minimal atau belum terlihat, dosis dapat diulangi (jarang 
diberikan lebih dari $1 \mathrm{mg} / \mathrm{kg}$ ). Jika efek yang diinginkan telah diperoleh, pemberian hidralazin secara oral dimulai dengan dosis 1-2 mg/kg/hari dibagi atas tiga dosis. Dosis dapat dinaikkan sampai efek yang diharapkan tercapai atau sampai mencapai dosis maksimum $5-7 \mathrm{mg} / \mathrm{kg} / \mathrm{hari}$ dalam 3 hari (atau $200 \mathrm{mg} / \mathrm{kg} / \mathrm{hari}$ ). ${ }^{13}$

Untuk pengobatan dengan vasodilator jangka panjang oral dapat dipakai hidralazin oral. ${ }^{19}$ Hidralazin banyak diberikan pada pasien dengan insufisiensi katup mitral atau aorta yang berat, pirau dari kiri ke kanan yang besar, kardiomiopati dan hipertensi pasca bedah. ${ }^{4,23}$

Hidralazin efektif dalam menurunkan tahanan vaskular ginjal dan meningkatkan aliran darah ginjal yang lebih besar dari vasodilator lain. Oleh karena itu hidralazin mungkin merupakan vasodilator pilihan pada pasien gagal jantung dengan gangguan fungsi ginjal yang tidak toleran dengan inhibitor $\mathrm{ACE} .{ }^{16}$

Efek samping meliputi nyeri kepala, nausea, muntah, demam, dan ruam. ${ }^{1,12}$ Sering dijumpai efek samping hidralazin yang berhubungan dengan ketidaksesuaian dosis atau penghentian tibatiba. ${ }^{16,28}$ Gejala ini biasanya hilang atau berkurang setelah beberapa waktu pemakaian atau dengan penurunan dosis. Efek samping dapat dikurangi atau dihindari dengan pemberian agonis beta adrenergik. Kontraindikasi hidralazin adalah pasien yang hipersensitif terhadap obat ini, karena dapat terjadi lupus eritematosus. ${ }^{7,12}$

Organik nitrat termasuk isosorbid dinitrat, telah banyak dipakai dalam penelitian besar untuk pengobatan kardiomiopati dewasa, tetapi pengalaman untuk pasien anak terbatas. ${ }^{1,23}$ Cara kerjanya mungkin mirip dengan nitrogliserin, yaitu melalui mekanisme oksida nitrit. ${ }^{23}$ Nitrat mempunyai masa kerja yang lebih panjang dari pada nitrogliserin. ${ }^{1}$ Dosis isosorbid dinitrat $5 \mathrm{mg} / 6$ jam, oral. ${ }^{4,14}$

Kaptopril adalah suatu inhibitor ACE yang akhir-akhir ini paling banyak dipakai untuk menurunkan preload dan after load. ${ }^{13}$ Enzym angiotensin converting mengkatalisis konversi angiotensin I yang inaktif menjadi angiotensin II, yang memegang peran dalam pengaturan tekanan darah dan keseimbangan air dan natrium. ${ }^{1,7}$ Kaptopril menghambat konversi tersebut sehingga kadar angiotensin II rendah, dengan perantara sistem kinin, prostaglandin dan kalikrin terjadilah vasodilatasi, sekresi aldosteron menurun, aliran darah ke ginjal meningkat sehingga sekresi natrium meningkat. ${ }^{29-33}$

Taraza dan kawan-kawan ${ }^{30}$ melaporkan keunggulan kaptopril bila dibandingkan dengan vasodilator lain karena obat ini dapat menurunkan kenaikan aldosteron yang sering terjadi pada pasien gagal jantung kongestif kronik. Beberapa manfaat kaptopril adalah, ${ }^{6}$

1. Dampak hemodinamik. Kaptopril dapat meningkatkan indeks jantung dan indeks pemompaan, menurunkan tekanan pengisian ventrikel kiri, menurunkan konsumsi oksigen miokardium, sedang frekuensi jantung normal atau turun.

2. Dampak pada ginjal. Kaptopril menurunkan tahanan vaskular ginjal, menaikkan aliran darah ke ginjal, meningkatkan ekskresi natrium, dan menyebabkan retensi kalium. Filtrasi glomerulus meningkat atau tetap.

3. Dampak fungsional. Kaptopril meningkatkan fraksi ejeksi ventrikel, mengurangi rasio jantungtoraks, serta meningkatkan toleransi latihan.

Shaddy RE dan kawan-kawan ${ }^{33}$ melaporkan pemakaian kaptopril pada pasien-pasien dengan pirau kiri ke kanan yang besar dan didapatkannya bahwa pemakaian kaptopril dalam jangka waktu pendek dapat menurunkan rasio aliran darah dari paru ke sirkulasi sistemik. Pemberian kaptopril oral akan diserap dengan cepat, adanya makanan akan mengurangi penyerapan, oleh karena itu obat ini sebaiknya diberikan 1 jam sebelum makan. ${ }^{1}$ Puncak kadar dalam plasma timbul dalam 1 jam, waktu paruh obat sekitar 2 jam, dan obat diekskresikan melalui air seni. Diperlukan penyesuaian dosis pada pasien pasien gangguan fungsi ginjal. ${ }^{1}$

First-dose effect dari kaptopril yang perlu sekali diawasi adalah terjadinya penurunan tekanan darah dengan cepat. Pada pasien yang sebelumnya telah memperoleh pengobatan dengan diuretik, penggunaan kaptopril dimulai dengan dosis rendah, diberikan di rumah sakit dengan pengawasan ketat. ${ }^{1,16,18}$ Efek yang tidak diinginkan dari kaptopril adalah neutropenia dan jika hal ini terjadi obat harus dihentikan. Efek samping lainnya adalah hipotensi, batuk, angioedema, proteinuria, agranulositosis, gagal ginjal akut dan hiperkalemia. ${ }^{34}$ Suplementasi kalium ataupun potassium-sparing diuretics (spironolactone) sebaiknya tidak diberikan karena dapat terjadi hiperkalemia. ${ }^{1,35}$ Batuk yang tidak produktif, salah satu efek samping dari inhibitor ACE, terjadi pada 3-15\% pemakai obat ini. ${ }^{27,29,35}$ Walaupun batuk ini merupakan hal yang tidak serius, kira-kira 5\% pasien 
terpaksa menghentikan pengobatan karena batuk yang persisten. ${ }^{31}$ Kontraindikasi absolut inhibitor ACE adalah stenosis arteri renal bilateral dan angioedema selama pemakaian ACE Inhibitor sebelumnya. ${ }^{35}$ Adanya riwayat ACE inhibitor-induced cough adalah kontraindikasi relatif. ${ }^{35}$

Enalapril merupakan inhibitor ACE baru dengan efek dan cara kerja yang mirip kaptopril, ${ }^{34}$ telah digunakan dalam pengobatan gagal jantung pada bayi dan anak, namun keterangan mengenai obat ini masih sangat terbatas. ${ }^{1}$ Enalapril mengalami deesterifikasi di hati dan membentuk zat aktif enalaprilat. Kurang lebih $60 \%$ dari dosis oral yang diabsorpsi, diekskresikan dalam bentuk yang tidak berubah di dalam urin dan dosis harus dikurangi pada pasien gangguan fungsi ginjal. ${ }^{1}$ Satu hal kelebihan enalapril dibanding kaptopril adalah masa kerjanya yang panjang maka frekuensi pemberian dalam satu hari dapat dikurangi. ${ }^{1}$

Nifedipin adalah kalcium channel blockers seperti nifedipin biasanya dipakai pada aritmia kordis dan hipertensi. ${ }^{20}$ Beberapa peneliti menggunakan pada pasien dengan gagal jantung kongestif. Nifedipin merupakan arteriolar dilator yang poten dan dapat menurunkan afterload, mempunyai efek inotropik negatif minimal. ${ }^{20}$ Jika diberikan dengan dosis besar dapat terjadi gangguan kontraktilitas jantung (impairment of cardiac contractility), oleh karena itu obat ini tidak merupakan obat pilihan. ${ }^{20}$

Minoksidil. Obat ini adalah relaksan otot polos yang poten, mempunyai efek dominan pada pembuluh arteriolar. ${ }^{20}$ Efek hemodinamik sangat mirip dengan efek yang ditimbulkan oleh hidralazin. Cardiac index, stroke volume index dan stroke index meningkat segera setelah tahanan vaskular sistemik menurun, tanpa menyebabkan penurunan tekanan darah. Mekanisme kerja pada anak masih dalam percobaan. Dosis untuk anak $0,25-1 \mathrm{mg} / \mathrm{kg} /$ hari. $^{20}$

Prazosin mempunyai efek untuk menurunkan preload dan afterload. ${ }^{1,20}$ Merupakan derivat quinazoline yang secara selektif dapat memblok postsynaptic alpha 1 adrenoreceptor di dinding pembuluh darah. ${ }^{20}$ Hipotensi kadang-kadang terjadi setelah pemberian dosis pertama prazosin. ${ }^{20}$ Dijumpai beberapa laporan mengenai first-dose phenomene berupa transient faintness, dizziness, palpitasi dan sinkop, karena itu dosis dimulai dengan dosis rendah dan ditingkatkan secara bertahap. ${ }^{4,22}$ Obat relatif tidak menimbulkan efek samping yang serius. Gejala gastrointestinal, sakit kepala, palpitasi dan drowsines kadang-kadang dapat terjadi. Efek samping lainnya yang pernah dilaporkan adalah artralgia, inkontinensia urin, ruam dan mulut kering. ${ }^{20}$ Beberapa jenis vasodilator baru seperti flosequinan, suatu derivat quinazoline yang bekerja sinergis dengan vasodilator lain; menimbulkan harapan baru untuk pengobatan gagal jantung. Dosis 1-1,5 mg/ kg satu kali sehari. ${ }^{11}$ Calcium channel blockers yang baru yaitu amlodifin dan felodifin, dapat menurunkan konsentrasi plasma norepinefrin, namun masih perlu dilakukan penelitian bagaimana dampaknya pada anak. ${ }^{11}$

\section{Kombinasi Vasodilator dengan Obat Lain}

Tatalaksana gagal jantung sering memerlukan pengobatan kombinasi. ${ }^{6}$ Misalnya kombinasi antara dopamin dosis rendah dengan dobutamin sering digunakan untuk gagal jantung berat atau syok kardiogenik. ${ }^{6}$ Kombinasi dopamin atau dobutamin dan nitroprusid dipakai pada pasien gagal jantung dengan curah jantung rendah pasca bedah jantung terbuka. ${ }^{6}$ Oleh karena kaptopril dapat menyebabkan sinkop atau hipotensi, pemakaian diuretik sebelum pemberian kaptopril dapat mengurangi efek tersebut. Kombinasi antara kaptopril oral dengan digoksin dapat dipakai untuk pengobatan jangka panjang kardiomiopati kongesti dengan atau tanpa insufisiensi aorta atau mitral berat. ${ }^{6}$ Pada gagal jantung kongesti, inhibitor ACE sering dikombinasi dengan diuretik dan digoksin. Digoksin dapat mengurangi besar dan frekuensi denyut jantung, sedangkan inhibitor ACE mengurangi load sehingga kombinasi ini dapat lebih memperbaiki hemodinamik jantung dari pada jika diberikan secara tunggal. $1,6,22$

\section{Kesimpulan}

Digitalis dan diuretik masih dipakai sebagai obat standar, namun akhir-akhir ini telah banyak dipakai vasodilator dalam tatalaksana gagal jantung pada bayi dan anak. Cara kerja vasodilator adalah mempengaruhi preload dan afterload. Pengobatan gagal jantung pada anak dengan vasodilator telah banyak dicoba dengan hasil memuaskan. Agar dapat dipilih obat yang tepat, perlu dipahami prinsip dasar fungsi jantung normal maupun abnormal, sifat spesifik masing-masing obat, dan keadaan klinis pasien. 
Untuk pemakaian jangka pendek, pada pasien dengan curah jantung yang rendah setelah operasi jantung, gagal jantung yang berat dan tidak terkontrol, drug of choice adalah nitroprusid IV. Untuk pemakaian jangka panjang pada pasien rawat jalan dapat diberikan hidralazin, prazosin, kaptopril, atau enalapril. Kaptopril adalah vasodilator yang paling banyak dipakai saat ini. Vasodilator sering dipakai bersama-sama (dikombinasikan) dengan diuretik dan atau digoksin. Ada beberapa jenis vasodilator baru seperti flosequinan dan calcium channel blockers baru seperti amlodifin dan felodifin yang menimbulkan harapan baru untuk pengobatan gagal jantung, namun masih perlu dilakukan penelitian bagaimana dampaknya pada anak.

\section{Daftar Pustaka}

1. Artman M, Graham TP, Ala M, Tenn N. Guidelines for vasodilator therapy of congestive heart failure in infants and children. Am Heart J 1987; 113:994-1003.

2. Wolfe RR, Boucek M, Schaffer MS, Wiggins JW. Major clues to heart disease in infants and children: congestive heart failure. Dalam: Way WW, Groothuis JR, Hayward AR, Levin MJ, penyunting. Current pediatric diagnosis $\&$ treatment, edisi ke-13. Stanford: Appletion \& Lange, 1997. h. 465-88.

3. Cohn JN, Franciosa JA. Vasodilator therapy of cardiac failure. Dikutip dari Tantra H, Budisantosa M. Vasodilator pada pengobatan payah jantung. Medika 1993; 19:45.

4. Roebiono PS. Tatalaksana gagal jantung pada bayi dan anak. Dalam: Putra ST. Roebiono PS, penyunting. Penyakit jantung pada anak: Investigasi dan tatalaksana penyakit jantung bawaan dan kegawatan kardiovaskuler. Disampaikan pada Simposium Nasional Kardiologi Anak II, Kursus Ekokardiografi Anak 1, Jakarta, 21-24 November 1997.

5. Harimurti GM. Emergency in pediatric cardiology. Disampaikan pada The $1^{\text {st }}$ Indonesia Heart Association and Institute Jantung Negara Joint Simposium, Medan 14-15 Agustus, 1999.

6. Oesman IN. Gagal Jantung. Dalam: Sastroasmoro S, Madiyono B, penyunting. Buku ajar kardiologi anak. Jakarta, Ikatan Dokter Anak Indonesia, 1994. h. 42539.

7. Bernstein D. Congestive heart failure. Dalam: Nelson WE, Behrman RE, Kliegman RM, Arvin AM, penyunting. Nelson textbook of pediatric, edisi ke-15, Philadelphia: Saunders, 1996. h. 1359-63.

8. Sastroasmoro S. Diagnosis dan tatalaksana kegawatan kardiovaskular pada bayi dan anak. Dalam: Putra ST, Advani N, Rahayoe AU, penyunting. Dasar-dasar diagnosis dan tatalaksana penyakit jantung pada anak. Disampaikan pada Simposium Nasional Kardiologi Anak
1, Jakarta, 23 November 1996.

9. Davies MK. Defenisi gagal jantung. Dalam: Ball SG, Campbell RWF, Francis GS, penyunting. Buku pedoman gagal jantung-International handbook of heart failure, alih bahasa Hermani Kalim. Jakarta: Hoechst Aktiengessellshaft, 1996. h. 1-12.

10. Redington A. Gagal jantung pada bayi dan anak. Dalam: Ball SG, Cambell RWF, Francis GS, penyunting. Buku pedoman gagal jantung. International hand book of heart failure, alih bahasa Hermani Kalim. Jakarta: Hoechst Aktiengessellshaft, 1996. h. 61-65.

11. Hoffman JIE, Stanger P. Congestive heart failure. Dalam: Rudolp AM, Hoffman JIE, Rudolp CD, penyunting. Rudolp's Pediatrics. Edisi ke-20, San Fransisco: Prentice Hall International, 1996. h. 1533-40.

12. Freed MD. Congestive Heart Failure. Dalam Fyler DC, penyunting. Nadas pediatric cardiology. Singapore: Info Access Distribution, 1992. h. 63-72.

13. Artman M, Graham TP, Tenn N. Congestive heart failure in infancy: Recognition and management. Am Heart J 1982; 103:1040-55.

14. Ghani A, Mochtar A, Hanafiah A, dkk. Gagal jantung kongestif pada anak dan bayi. Dalam: Josoef AH, Kalim H, Karo-karo S, Soerianta S, penyunting. Pedoman tatalaksana gagal jantung. Jakarta: Persatuan Dokter Spesialis Kardiovaskuler Indonesia ,1996. h. 29-30.

15. Katzung BG, Parmley WW. Glikosida jantung dan obatobatan lain yang digunakan dalam pengobatan payah jantung kongestif. Dalam: Katzung BG. Farmakologi dasar dan klinik (Basic and clinical pharmacology). Edisi ke-3, Jakarta: Penerbit Buku Kedokteran EGC, 1997. h. $165-80$.

16. Kelly RA, Smith TW. Pharmacological treatment of heart failure. Dalam: Goodman \& Gilman's. The pharmacological basis of therapeutics. Edisi ke-9, New York: Mc Graw-Hill, 1996. h. 809-38.

17. Baraas F. Kardiologi klinis dalam praktek diagnosis dan tatalaksana penyakit jantung pada anak. Jakarta: FKUI, 1995. h. 236-43.

18. Muchtar A, Bustami ZS. Obat gagal jantung. Dalam: Ganiswarna SG, Setiabudy R, Suyatna FD, Purwantyastuti, Nafrialdi, penyunting. Farmakologi \& therapy. Edisi ke-4, Jakarta: Bagian Farmakologi FKUI, 1995.h.271-88.

19. Artman M, Parrish MD, Graham TP, Congestive heart failure in childhood and adolescence: Recognition and management. Am Heart J 1983; 103:471-80.

20. Chan KY, Yip WCL, Tay JSH. Cardiovascular pharmacological therapy in children-a review. Part 2: Vasodilators and diuretics. The Journal of Singapore Paediatric Society 1988; 30:100-7.

21. Wilson PAP. Current theurapeutic principles in acute management of severe congestive heart failure. Am J Cardiol 1988; 62:4c-8c.

22. Opie LH, Wilson PAP, Sonnelblick E, Chatterjee K. Angiotensin-converting enzyme inhibitor, contrast with conventional vasodilators. Dalam: Opie LH, Phil D. Drugs for the heart, edisi ke 4. Philadelphia: Saunders, 1997. h. 5-42.

23. Talner NS. Heart failure. Dalam: Emmanouilides GC, 
Reimenschneider TA, Allen HD, Gutgesell HP, penyunting. Moss and Adams, Heart disease in infants, children and adolescents, including the fetus and young adults, edisi ke-5. Baltimore: Williams and Wilkins, 1995. h. 1746-71.

24. Veldhuisen DJ, Genth Zotz S, Brouwer J, dkk. High versus low dose ACE Inhibition in chronic heart failure a double-blind, placebo-controlled study of imipramil. J Am Coll Cardiol 1998; 32:1811-8.

25. Wangge MNT. Pengobatan gagal jantung mutakhir. Maj Kedok Indon 1999; 49:102-11.

26. Francis GS. Heart failure management. The impact of drug therapy on survival. Am Heart J 1988; 115:699-701.

27. Benson LN, Bohn D, Edmons JF dkk. Nitroglycerine therapy in children with low cardiac index after heart surgery. Dikutip dari Chan KY, Yip WCL, Tay JSH. Cardiovascular pharmacological therapy in children - a review. Part 2: Vasodilators and diuretics. The journal of Singapore Paediatric Society 1988; 30:100-7.

28. Cahtterye K. Vasodilator therapy of heart failure. Dikutip dari Tantra H, Budisantosa M. Vasodilator pada pengobatan payah jantung. Medika 1993; 19:450-9.

29. Cohn JN, Archibald, Ziesche S, dkk. Effect of vasodilator therapy in chronic congestive heart failure. Dikutip dari Kelly RA, Smith TW. Pharmacological treatment of heart failure. Dalam: Goodman \& Gilman's, The pharmacological Basis of therapeutics. Edisi ke-9, New York: Mc Graw-Hill, 1996. h. 809-38.

30. Taraza RC, Fouad FM, Ceimo JK, Bravo EL. Renin aldosterone and cardiac decompensation: Studies with an oral converting enzyme inhibitor in heart failure. Dikutip dari Artman M, Parrish MD, Graham TP. Congestive heart failure in childhood and adolescence: Recognition and management. Am Heart J 1983; 103:479.

31. Sasaguri M, Ideishi M, Kinoshita A, Arakawa K. Differential inhibition of bradykinin hydrolysis by four ACE Inhibitors: a posibble explanation for differencies in induced coughing. Hipertens Res 1994; 17:235-58.

32. Cleland JGF, Dargie HJ, Hodsman GP, dkk. Captoril in heart failure. A double-blind controlled trial. Dikutip dari Parmley WW. Factors causing arrythmias in chronic congestive heart failure. Am Heart J 1987; 114:126572.

33. Shaddy RE, Teitel DF, Brett C. Short term hemodynamic effect of kaptopril in infants with congestive heart failure. Am J Dis Child 1988; 142:100-105.

34. Cody RJ. Angiotensin-Converting Enzyme Inhibitors in treatment of heart failure. Practical cardiology 1986; 12:108-16.

35. The Task Force of the Working Group on Heart Failure of the European Society of Cardiology. The treatment of heart failure. Eur Heart J 1997; 18:736-53. 